\title{
'\#Refugees can be entrepreneurs too!' Humanitarianism, race, and the marketing of Syrian refugees
}

\author{
Lewis Turner* (D) \\ Arnold Bergstraesser Institute at the University of Freiburg, Germany \\ ${ }^{*}$ Corresponding author. Email: lewis.turner@abi.uni-freiburg.de
}

(Received 22 December 2018; revised 18 September 2019; accepted 19 September 2019;

first published online 25 October 2019)

\begin{abstract}
In the context of a greater focus on the politics of migration, the 'refugee entrepreneur' has become an increasingly important figure in humanitarian, media, and academic portrayals of refugees. Through a focus on Jordan's Za'tari refugee camp, which has been deemed a showcase for refugees' 'entrepreneurship', this article argues that the designation of Syrian refugees as 'entrepreneurs' is a positioning of Syrians within colonial hierarchies of race that pervade humanitarian work. For many humanitarian workers in Jordan, Syrians' 'entrepreneurship' distinguishes them from 'African' refugees, who are imagined as passive, impoverished, and dependent on humanitarian largesse. Without explicit racial comparisons, humanitarian agencies simultaneously market Syrian refugees online as 'entrepreneurs', to enable them to be perceived as closer to whiteness, and to thereby render them more acceptable to Western audiences and donors, who are imagined as white. This article extends scholarly understandings of the understudied relationship between race and humanitarianism. Furthermore, it asks critical questions about the political work and effects of vision of the 'refugee entrepreneur', which it locates within the context of the increasingly neoliberalised refugee regime. 'Refugee entrepreneurs' do not need political support and solidarity, but to be allowed to embrace the forces of free-market capitalism.
\end{abstract}

Keywords: Humanitarianism; Race; Syrian Refugees; Za'tari Refugee Camp; UNHCR; Entrepreneurship

\section{Introduction}

'Did you hear? @ZaatariCamp is now serving pizza! \#Refugees can be entrepreneurs too!'

In contrast to longstanding portrayals of refugees as passive and dependent on the largesse of humanitarian organisations, in recent years the 'refugee entrepreneur' has emerged as a significant figure in humanitarian, media, and academic portrayals of refugees. Positioning refugees as 'entrepreneurs' is both the latest iteration of a longstanding humanitarian emphasis on refugee 'self-reliance', and a reflection of the changing nature of humanitarianism, which increasingly promotes 'innovation' and 'resilience' among refugee populations, in lieu of re-establishing the severed connection between state and citizen that refugeehood represents. ${ }^{2}$ Simultaneously, the

\footnotetext{
${ }^{1}$ USA for UNHCR, 'Did You Hear? @ZaatariCamp Is Now Serving Pizza! \#Refugees Can Be Entrepreneurs Too!', Twitter post, available at: \{https://twitter.com/UNRefugeeAgency/status/571419549318434816\} accessed 20 July 2018.

${ }^{2}$ Mark Duffield, 'The liberal way of development and the development - security impasse: Exploring the global life-chance divide', Security Dialogue, 41:1 (2010), pp. 53-76; Mark Duffield, 'Challenging environments: Danger, resilience and the aid industry', Security Dialogue, 43:5 (2012), pp. 475-92; Evan Easton-Calabria and Naohiko Omata, 'Panacea for the refugee crisis? Rethinking the promotion of "self-reliance" for refugees', Third World Quarterly, 39:8 (2018), pp. 1458-74; Suzan

(c) British International Studies Association 2019. This is an Open Access article, distributed under the terms of the Creative Commons Attribution licence (http://creativecommons.org/licenses/by/4.0/), which permits unrestricted re-use, distribution, and reproduction in any medium, provided the original work is properly cited.
} 
promotion of 'refugee entrepreneurs' can be understood as part of attempts, through an emphasis on refugees' agency and creativity, to re-imagine refugees as an 'opportunity' or a 'resource', rather than a 'burden' or a 'threat'. ${ }^{3}$ Some therefore deploy the idea of 'refugee entrepreneurship' in an attempt to challenge and change narratives that feed hostility towards refugees. Yet, as this article will demonstrate through a critical analysis of humanitarian understandings and depictions of the Syrian 'refugee entrepreneurs' of Za 'tari refugee camp in Jordan, ${ }^{4}$ in this context the vision of 'refugee entrepreneurs' is inextricably intertwined with processes of racialisation, which serve to reproduce both white supremacy and anti-black racism.

Specifically, this article argues that humanitarian designations of Syrian refugees in Za'tari as 'entrepreneurs' is a positioning of Syrian refugees within and relative to the racial hierarchies that have long pervaded humanitarian work. In 'the field', many humanitarians informally but explicitly position Syrian refugees as 'non-African'. In their creativity, energy, and focus on what is deemed 'entrepreneurship', Syrian refugees are regularly understood to be both distinct from and superior to 'African' refugees, with whom many humanitarians are more accustomed to working, and who occupy a central position in how refugeehood and humanitarianism are often imagined. This designation of Syrians as 'entrepreneurs' simultaneously reproduces the longstanding idea of Syrians as 'Levantine', and thereby somehow 'natural' traders. These new processes of racialisation, therefore, map onto their equally problematic predecessors. In online articles, tweets, and commentary, however, humanitarian actors' explicit comparisons with 'Africans' disappear, as they attempt to portray Syrians in Za'tari as 'entrepreneurs' in order to enable them to be perceived as closer to whiteness, and to thereby generate sympathy and acceptance for them among middle-class, Western audiences and donors, who are imagined as white. In this context, therefore, the positioning of Syrian refugees as 'entrepreneurs' is inseparable from white supremacy and anti-blackness. Humanitarian actors rely on, and reproduce, globally circulating colonial hierarchies of race, which mediate their interactions with, and understandings of, the Syrian population of $\mathrm{Za}$ 'tari.

In the context of $\mathrm{Za}^{\prime}$ tari, as in all contexts, there are multiple (often overlapping) rationalities that structure and inform humanitarianism. By foregrounding the racialised hierarchies of humanitarianism, in official and unofficial humanitarian discourses and ideas, I am purposefully centring a crucial yet understudied aspect of humanitarian work. In doing so, I offer two central contributions to scholarship. Firstly, this article responds to Adia Benton's call for greater engagement with 'professional humanitarianism's thorny and under-examined relationship with antiblackness and white supremacy'. As will shortly be discussed, questions of race are similarly marginalised and under-studied within the discipline of International Relations (IR) as a whole. In responding to Benton's call, and to the wider shortage of analyses of race and racialisation within IR, the article expands scholarly understandings of the centrality of race and racial hierarchies to humanitarianism, by demonstrating some of the ways in which race is operationalised in discussions and portrayals of 'refugee entrepreneurship'. In line with the broader trend of using the study of 'micro-moves' to shed light on broader concepts and processes in $\mathrm{IR}^{6}{ }^{6}$ it

Ilcan and Kim Rygiel, "Resiliency humanitarianism”: Responsibilizing refugees through humanitarian emergency governance in the camp', International Political Sociology, 9:4 (2015), pp. 333-51; Tom Scott-Smith, 'Humanitarian neophilia: the "innovation turn" and its implications', Third World Quarterly, 37:12 (2016), pp. 2229-51.

${ }^{3}$ See Alexander Betts, Louise Bloom, and Naohiko Omata, 'Humanitarian Innovation and Refugee Protection', Working Paper Series (Oxford: Refugee Studies Centre, 2012).

${ }^{4}$ Except when quoting others, I use the spelling Za'tari, following the International Journal of Middle East Studies (IJMES) transliteration guidelines, while using a single quotation mark ' in place of the diactric '. Other transliterations of Arabic conform to the IJMES style, except for diacritics, which are omitted.

${ }^{5}$ Adia Benton, 'African expatriates and race in the anthropology of humanitarianism', Critical African Studies, 8:3 (2016), p. 267.

${ }^{6}$ Ty Solomon and Brent J. Steele, 'Micro-moves in International Relations theory', European Journal of International Relations, 23:2 (2017), pp. 267-91. 
contributes to a 'deepen[ing of] the evidentiary base for claims linking race ... and humanitarianism'. It furthermore does so through a focus on a context - Za'tari camp - that has become one of the key sites for imagining the 'refugee crisis'.

Secondly, this article asks critical questions about the political work and effects of the figure of the 'refugee entrepreneur', and thereby also contributes to debates on both portrayals of refugees and the changing nature of the contemporary humanitarian system. The terminology of 'refugee entrepreneurship' is often incorporated in both academic and non-academic production on refugees, which can thereby reproduce and reinforce the racialised hierarchies that create surprise and even amazement at the skills of Syrians. Even when narratives of 'entrepreneurship' do not involve the same explicit racial comparisons, the perceived connotations of the 'entrepreneurial ideal' mean that these designations still contain positionings of refugees relative to hierarchies of race, as well as gender, class, and ability. The narrative of 'refugee entrepreneurs' furthermore instrumentalises the survival strategies of marginalised populations. In line with 'resiliency humanitarianism', 9 it shifts attention to how refugees can (and thus implicitly should) adapt to their new circumstances, rather than facilitating demands for human rights, political change, and humanitarian support. 'Refugee entrepreneurs' do not need the support of states or humanitarians, but rather to be allowed to embrace the forces of free-market capitalism. ${ }^{10}$

The article proceeds by firstly outlining how, despite scholarly production on the centrality of race to the ways in which the figure of 'the refugee' has been popularly imagined, scholarship on humanitarianism largely replicates the broader 'racial aphasia' of the discipline of IR. ${ }^{11}$ Subsequently, a background to Za'tari is provided, including an exploration of the camp's market, which is central to portrayals of the camp as a space of 'entrepreneurship'. The article then tackles, in turn, different aspects of the racialisations involved in the designation of Syrians as 'entrepreneurs'. Firstly, it analyses how humanitarian actors' relationships with Syrians are mediated by understandings of Syrians as 'non-African', and sometimes as 'Levantine', before examining how Syrians are positioned as 'entrepreneurs' in humanitarian online content, in order to enable them to be perceived, by Western audiences, as closer to whiteness. These portrayals, it demonstrates, are regularly replicated in both media and academic production on refugees in $\mathrm{Za}$ 'tari. Following this, the article examines the implications of these arguments for portrayals of non-Syrian refugees as 'refugee entrepreneurs', before finally considering the place of 'refugee entrepreneurs' in the evolving humanitarian system.

The analysis presented here is primarily based on fieldwork in Jordan that took place from September 2015 to August 2016. This fieldwork included 27 days of participant and nonparticipant observation in Za'tari, primarily through my work with the Jordanian NGO Arab Renaissance for Democracy and Development (ARDD), and via a research permit from the Jordanian Ministry of Interior. Over the course of this fieldwork, I conducted semi-structured interviews with 28 humanitarian and NGO workers; 10 officials from donor agencies, think tanks, and the private sector; and 32 Syrian refugees living inside and outside of the camp. Many of the Syrian interviewees in Za'tari were working in the camp's market, and others

\footnotetext{
${ }^{7}$ Adia Benton, 'Risky business: Race, nonequivalence and the humanitarian politics of life', Visual Anthropology, 29:2 (2016), p. 187.

${ }^{8}$ Alexander Betts, Louise Bloom, and Nina Weaver, 'Refugee Innovation: Humanitarian Innovation That Starts with Communities' (Oxford: Refugee Studies Centre, 2015).

${ }^{9}$ Ilcan and Rygiel, "'Resiliency humanitarianism"'; see also Sarah A. Tobin and Madeline Otis Campbell, 'NGO governance and Syrian refugee "subjects" in Jordan', Middle East Report, 278 (2016), pp. 4-11.

${ }^{10}$ See Easton-Calabria and Omata, 'Panacea for the refugee crisis?'; Randy Lippert, 'Governing refugees: the relevance of governmentality to understanding the international refugee regime', Alternatives: Global, Local, Political, 24:3 (1999), pp. 295-328; Scott-Smith, 'Humanitarian neophilia'.

${ }^{11}$ Debra Thompson, 'Through, against and beyond the racial state: the transnational stratum of race', in Alexander Anievas, Nivi Manchanda, and Robbie Shilliam (eds), Race and Racism in International Relations: Confronting the Global Colour Line (Abingdon, Oxon and New York: Routledge, 2015), pp. 44-61.
} 
were 'volunteering' for humanitarian organisations through 'Cash for Work' schemes. Interviews were conducted with Syrians in Arabic, and with humanitarian workers primarily in English (although some included exchanges in Arabic). All of my Syrian interviewees, and the vast majority of humanitarian interviewees, have been anonymised, at their request. In addition to these more formal interviews, the article draws on numerous informal conversations and interactions with Syrian refugees and humanitarian workers, both inside and outside of Za'tari. The deployment of this in-depth, textured, ethnographically informed analysis, comes in the context of a wider movement in the discipline of IR to analyse 'where structures are enacted and contested', and to do so 'through the lenses of lived, embodied and experiential everyday processes'. ${ }^{12}$ Furthermore, drawing on Stuart Hall's insights into intertextuality, the article analyses humanitarian actors' online communications about the camp, with a focus on websites and twitter accounts run by the United Nations High Commissioner for Refugees (UNHCR), which, together with the Jordanian Government, governs Za'tari camp.

\section{Race, refugees, and International Relations}

As numerous scholars have demonstrated, despite its importance in both the foundation of the discipline, and its centrality to international politics, the topic of race is typically absent from IR scholarship. ${ }^{13}$ The discipline suffers from racial aphasia, a 'calculated forgetting, an obstruction of discourse, language and speech'. ${ }^{14}$ Nevertheless, while academic work on race and IR remains a 'marginal enterprise, ${ }^{15}$ there has been a noticeable increase in the volume of academic production on race in/and IR. ${ }^{16}$ Of particular relevance to the analysis presented in this article, is this scholarship's clear demonstration that the racial structures created by slavery, colonialism, and capitalism continue to be central to the operations of international politics, the workings of contemporary capitalism, and the racialised nature of the global order. ${ }^{17}$ Patrick Wolfe thus describes race as 'colonialism speaking', and racialisation as the 'active productivity of race', which does not describe human groups, but rather 'brings them into being. ${ }^{18}$ Colonised populations, Wolfe explains, 'continue to be racialised in specific ways that mark out and reproduce ... unequal relationships' ${ }^{19}$ While this article is primarily grounded in IR scholarship, these points have of course similarly been demonstrated in a range of disciplines, especially in Black studies, African American studies, cultural studies, and the literature on racial capitalism. ${ }^{20}$

\footnotetext{
${ }^{12}$ Solomon and Steele, 'Micro-moves in International Relations theory', pp. 267, 275.

${ }^{13}$ Alexander Anievas, Nivi Manchanda, and Robbie Shilliam, 'Confronting the global colour line: an introduction', in Anievas, Manchanda, and Shilliam (eds), Race and Racism in International Relations, pp. 1-15; Siba N. Grovogui, 'Come to Africa: a hermeneutics of race in international theory', Alternatives: Global, Local, Political, 26:4 (2001), pp. 425-48; Robert Vitalis, White World Order, Black Power Politics: The Birth of American International Relations (Ithaca: Cornell University Press, 2015). Errol A. Henderson, 'Hidden in plain sight: Racism in International Relations theory', Cambridge Review of International Affairs, 26:1 (2013), pp. 71-92.

${ }^{14}$ Thompson, 'Through, against and beyond the racial state', p. 45.

${ }^{15}$ Duncan Bell, 'Race and International Relations: Introduction', Cambridge Review of International Affairs, 26:1 (2013), p. 2.

${ }^{16}$ Anievas, Manchanda, and Shilliam, 'Confronting the global colour line'.

${ }^{17}$ Bell, 'Race and International Relations'; Branwen Gruffydd Jones, 'Race in the ontology of international order', Political Studies, 56:4 (2008), pp. 907-27; Olivia Umurerwa Rutazibwa, 'From the everyday to IR: In defence of the strategic use of the R-word', Postcolonial Studies, 19:2 (2016), pp. 191-200; Alina Sajed, 'Fanon, Camus and the global colour line: Colonial difference and the rise of decolonial horizons', Cambridge Review of International Affairs, 26:1 (2013), pp. 5-26; Robbie Shilliam, 'Race and research agendas', Cambridge Review of International Affairs, 26:1 (2013), pp. 152-8. Similar arguments were of course made a long time ago within the discipline, although this work was often ignored and/or marginalised. See, for example, W. E. B. Du Bois, 'Worlds of color', Foreign Affairs, 3:3 (1925), pp. 423-44.

${ }^{18}$ Patrick Wolfe, Traces of History: Elementary Structures of Race (London and New York: Verso, 2016), pp. 4, 10.

${ }^{19}$ Ibid., p. 2.

${ }^{20}$ Prominent examples of such scholarship include Gargi Bhattacharyya, Rethinking Racial Capitalism: Questions of Reproduction and Survival (London and Lanham, MD: Rowman \& Littlefield, 2018); Angela Davis, Women, Race, \& Class (New York: Vintage, 1983); Walter Johnson, 'To remake the world: Slavery, racial capitalism, and justice', Boston
} 
Scholarship on humanitarianism replicates the aforementioned broader sidelining of race. As Adia Benton has argued, central theoretical concepts in humanitarianism scholarship, such as Fassin's humanitarian politics of life, have 'little regard to the kinds of social distinctions between humans, like race, that precede and are intensified by the humanitarian encounter. ${ }^{21}$ As in IR as a whole, however, there is a small and growing number of critical scholars who have challenged the racial aphasia of analyses of humanitarianism. In recent years, scholars have produced analyses of race and the politics of celebrity humanitarianism, racialised humanitarian imagery, racialised hierarchies of power within humanitarian organisations, and the racial politics of 'Tinder humanitarians'. ${ }^{22}$ Scholars have similarly demonstrated that race has been central to the responses of European states to refugees and migrants, even if the 'brute racial fact of this deadly European border regime is seldom acknowledged'. ${ }^{23}$ Race has also been crucial in the analysis of some scholars working on related fields, most notably development and intervention, in which the subject is similarly regularly ignored or sidelined. ${ }^{24}$

While the relative absence of race within work on humanitarianism is explicable, given the broader patterns of knowledge production noted above, it is even more striking that much scholarship on humanitarianism and refugee politics largely ignores race, ${ }^{25}$ given that scholars have demonstrated the centrality of racial hierarchies to humanitarian work, and the importance of race in how the figure of 'the refugee' has been imagined. B. S. Chimni has demonstrated that, in Northern imaginaries during the era of the Cold War, refugees were typically those fleeing communist regimes, and thus politically useful to Northern states because they could be mobilised as evidence of communist repression. A concomitant "image of a "normal" refugee was constructed - white, male and anti-communist'. ${ }^{26}$ Following the growing perception in the 1980s that more non-white, Southern refugees were coming to the North, the image of the refugee shifted from the 'heroic, political individual to a nameless flood of poverty-stricken women and children', and Africa became increasingly central to how refugeehood was imagined. ${ }^{27}$ The figure of the refugee was subject, Johnson argues, to interconnected processes of feminisation, depoliticisation,

Review Forum, 1 (2017), pp. 11-31; Cedric Robinson, Black Marxism: The Making of the Black Radical Tradition (Chapel Hill, NC: University of North Carolina Press, 2000); Gloria Wekker, White Innocence: Paradoxes of Colonialism and Race (Durham, NC and London: Duke University Press, 2016); Frank B. Wilderson III, Red, White \& Black: Cinema and the Structure of U.S. Antagonisms (Durham, NC: Duke University Press, 2010).

${ }^{21}$ Benton, 'Risky business', p. 190.

${ }^{22}$ Benton, 'African expatriates and race in the anthropology of humanitarianism'; Benton, 'Risky business'; Patricia Daley, 'Rescuing African bodies: Celebrities, consumerism and neoliberal humanitarianism', Review of African Political Economy, 40:137 (2013), pp. 375-93; Corinne Lysandra Mason, 'Tinder and humanitarian hook-ups: the erotics of social media racism', Feminist Media Studies, 16:5 (2016), pp. 822-37; Jemima Repo and Riina Yrjölä, 'The gender politics of celebrity humanitarianism in Africa', International Feminist Journal of Politics, 13:1 (2011), pp. 44-62; Lisa Ann Richey, “Tinder humanitarians": the moral panic around representations of old relationships in new media', Javnost - The Public, 23:4 (2016), pp. 398414.

${ }^{23}$ Nicholas De Genova, 'The "migrant crisis" as racial crisis: Do black lives matter in Europe?', Ethnic and Racial Studies, 41:10 (2018), p. 1766, emphasis in original; see also Ida Danewid, 'White innocence in the black Mediterranean: Hospitality and the erasure of history', Third World Quarterly, 38:7 (2017), pp. 1674-89; Luca Mavelli, 'Governing populations through the humanitarian government of refugees: Biopolitical care and racism in the European refugee crisis', Review of International Studies, 43:5 (2017), pp. 809-32.

${ }^{24}$ See, for example, Barbara Heron, Desire for Development: Whiteness, Gender, and the Helping Imperative (Waterloo, ON: Wilfrid Laurier University Press, 2007); Meera Sabaratnam, Decolonising Intervention: International Statebuilding in Mozambique (London and Lanham, MD: Rowman \& Littlefield International, 2017); Kalpana Wilson, Race, Racism and Development: Interrogating History, Discourse and Practice (London and New York: Zed Books, 2012).

${ }^{25}$ Lucy Mayblin, Asylum after Empire: Colonial Legacies in the Politics of Asylum Seeking (London and New York: Rowman \& Littlefield International, 2017); Prem Kumar Rajaram, 'Refugees as surplus population: Race, migration and capitalist value regimes', New Political Economy, 23:5 (2018), pp. 627-39.

${ }^{26}$ B. S. Chimni, 'Geopolitics of refugee studies: a view from the south', Journal of Refugee Studies, 11 (1998), p. 351; see also Gil Loescher, The UNHCR and World Politics: A Perilous Path (Oxford; New York: Oxford University Press, 2001).

${ }^{27}$ Heather L. Johnson, 'Click to donate: Visual images, constructing victims and imagining the female refugee', Third World Quarterly, 32:6 (2011), p. 1016; see also Liisa H. Malkki, 'Speechless emissaries: Refugees, humanitarianism, and 
and racialisation, ${ }^{28}$ demonstrating, once again, the inextricability of axes of power and differentiation such as race and gender. ${ }^{29}$ This depiction constituted a notable contrast to some previous visions of refugees in sub-Saharan Africa, who in the 1970s for example were often depicted as representing an opportunity for economic growth and rural development. ${ }^{30}$ The feminised image of refugeehood, as Jennifer Hyndman and Wenona Giles argue, is centrally associated with refugee populations living in the South, especially those populations living in protracted displacement, such as Syrian refugees in Jordan. By contrast, refugees who are moving from the South to the North are depicted as threatening to the security and/or welfare systems of states in the North. ${ }^{31}$ In the context of the so-called European 'migration crisis', young male refugees in particular were positioned, in media portrayals and political discourse, as threatening to European states and populations. ${ }^{32}$

The generic figure of the 'entrepreneur' is also a gendered and racialised subject position. For many people, including a wide range of humanitarians working in $\mathrm{Za}$ 'tari, this generic subject position stands in sharp contrast to the generic figure of the refugee in the South described above. As Melanie Knight has argued, the ideal of 'entrepreneurship' is associated with whiteness 'through the privileging of abstract thinking [and] mobility', while the 'management and selfdiscipline required serve to legitimize a white, male, liberal, able-bodied subject'. ${ }^{33}$ More widely, Knight continues, feminists have demonstrated that the built-in ideals of 'entrepreneurship' and the 'industrious, autonomous, disciplined, success-driven self ... negat[e] histories of oppression; sociolegal and political systemic barriers; and social context'. ${ }^{34}$ In a similar vein, in her extensive analysis of race and development, Kalpana Wilson has demonstrated that within capitalist accumulation under colonialism, a system that was 'productive of material and embodied difference on a global scale, ${ }^{35}$ whiteness became conflated with 'the capitalist virtues of dynamism and enterprise'. ${ }^{36}$

Whether practices are deemed to constitute 'entrepreneurship' is a judgement that is always 'claimed and contested in a wider field of power relations', and thus the idea of 'entrepreneurship' does not signify a 'productive economic role or disposition outside of cultural meaning' ${ }^{37}$ Rather, to give one example, the 'entrepreneurialism' of communities in the Global South is 'discovered' as part of attempts to bestow 'a form of neoliberal agency upon Third World subjects' ${ }^{38}$ As this article will discuss in further detail, the activities of some populations are interpreted as 'entrepreneurial' because they are 'known' to be more 'naturally entrepreneurial'. This analysis

dehistoricization', Cultural Anthropology, 11:3 (1996), pp. 377-404; Chris Methmann, 'Visualizing climate-refugees: Race, vulnerability, and resilience in global liberal politics', International Political Sociology, 8:4 (2014), pp. 416-35.

${ }^{28}$ Johnson, 'Click to donate'.

${ }^{29}$ Kimberlé W. Crenshaw, 'Demarginalizing the Intersection of Race and Sex: A Black Feminist Critique of Antidiscrimination Doctrine, Feminist Theory and Antiracist Politics', University of Chicago Legal Forum (1989), pp. 139-67.

${ }^{30}$ Joël Glasman, 'Seeing like a refugee agency: a short history of UNHCR classifications in Central Africa (1961-2015)', Journal of Refugee Studies, 30:2 (2017), pp. 337-62.

${ }^{31}$ Jennifer Hyndman and Wenona Giles, 'Waiting for what? The feminization of asylum in protracted situations', Gender, Place \& Culture, 18:3 (2011), pp. 361-79.

${ }^{32}$ Lesley Pruitt, Helen Berents, and Gayle Munro, 'Gender and age in the construction of male youth in the European migration "crisis", Signs: Journal of Women in Culture and Society, 43:3 (2018), pp. 687-709.

${ }^{33}$ Melanie Knight, "New markets must be conquered": Race, gender, and the embodiment of entrepreneurship within texts', The Canadian Geographer [Le Géographe Canadien], 57:3 (2013), p. 345. For a related analysis of the figure of homo oeconomicus, see Sylvia Wynter, 'Unsettling the coloniality of being/power/truth/freedom: Towards the human, after man, its overrepresentation - an argument', CR: The New Centennial Review, 3:3 (2003), pp. 257-337.

${ }^{34}$ Knight, “New markets must be conquered"', p. 348.

${ }^{35}$ Wilson, Race, Racism and Development, p. 17.

${ }^{36}$ Ibid., p. 38.

${ }^{37}$ John Tofik Karam, 'A cultural politics of entrepreneurship in nation-making: Phoenicians, Turks, and the Arab commercial essence in Brazil', Journal of Latin American Anthropology, 9:2 (2004), p. 339.

${ }^{38}$ Wilson, Race, Racism and Development, p. 39. 
means that designations of 'entrepreneurship', such as those in and about Za'tari, must be analysed and understood within the specific contexts in which they are made. The meanings of those designations emerge from that context, and the wider sets of power relations in which it exists. ${ }^{39}$

Encouraging and spreading the gendered, racialised, classed, and ableist mode of personhood represented by the generic figure of the 'entrepreneur' is furthermore central to numerous interventions in the South, which typically take place under the rubric of 'development', and often target women in particular. These interventions articulate with broader neoliberal economic discourses, in which self-enterprising citizen-subjects forge their way ahead in the absence of state support, and in which micro-finance is the cure of poverty. ${ }^{40}$ Actors such as the World Bank, among many others, focus on fostering 'entrepreneurial' cultures, creating new women 'entrepreneurs' as a means to promote gender equality, and facilitating access to capital and markets for women 'entrepreneurs'. ${ }^{41}$ These projects represent a form of neoliberal subject formation, focused on creating 'entrepreneurial', individualistic selves, ${ }^{42}$ and are part of the broader work of 'development', which is, as Wilson argues, 'always, also, implicitly about race'. ${ }^{43}$

The refugee regime is similarly increasingly being reimagined as centred not around restoring the link between the state and citizen through resettlement, integration into the host society, or voluntary return to the country of origin, but rather around the neoliberal notions of the 'resilience', 'adaptability', and 'entrepreneurship' of refugees. ${ }^{44}$ Refugees are increasingly, like others subject to neoliberal governance, ${ }^{45}$ expected to fend for themselves. As Nora Bardelli argues, the 'solution' to displacement is therefore increasingly defined in developmental terms, and has become 'a matter of access to the job market rather than a political question about inequalities, exclusion, conflict, exploitation, assymetrical power relations, and so on'. ${ }^{46}$ In this vein, high-profile proposals have argued that the economic hopes of Za'tari's residents lay in their integration into the low-wage workforces of nearby Special Economic Zones. ${ }^{47}$ But in Za'tari, to the surprise of many humanitarian workers, Syrian refugees did not need to be 'taught' 'entrepreneurialism'. Their independent economic activity represented a phenomenon that camp authorities aimed to constrain and manage, but also to harness in their attempts to market Syrian refugees to the outside world.

\section{Za'tari refugee camp and its market}

On the instructions of the Jordanian government, Za'tari camp was established in July 2012, about ten kilometres from the border with Syria, and on the edge of a Jordanian village from which the camp takes its name. While the camp population fluctuated extensively in the first two years of its existence, since the summer of 2014 around 80,000 Syrians have been living

\footnotetext{
${ }^{39}$ See Bhattacharyya, Rethinking Racial Capitalism.

${ }^{40}$ Aihwa Ong, Neoliberalism as Exception: Mutations in Citizenship and Sovereignty (Durham, NC and London: Duke University Press, 2006); Elisa Pascucci, 'Refugees in the IT sector: Young Syrians' economic subjectivities and familial lives in Jordan', Geographical Review, 109:4 (2018), pp. 580-97; Mayssoun Sukarieh, 'On class, culture, and the creation of the neoliberal subject: the case of Jordan', Anthropological Quarterly, 89:4 (2016), pp. 1201-25.

${ }^{41}$ See, for example, Kate Bedford, Developing Partnerships: Gender, Sexuality, and the Reformed World Bank (Minneapolis and London: University of Minnesota Press, 2009); Kalpana Wilson, "Race”, gender and neoliberalism: Changing visual representations in development', Third World Quarterly, 32:2 (2011), pp. 315-31.

${ }^{42}$ Sukarieh, 'On class, culture, and the creation of the neoliberal subject'.

${ }^{43}$ Wilson, Race, Racism and Development, p. 3.

${ }^{44}$ Ilcan and Rygiel, "Resiliency humanitarianism"; see also Hanno Brankamp, 'TEDx comes to the refugee camp (AKA think your way out of oppression!)', African Arguments, available at: \{https://africanarguments.org/2018/06/12/tedx-comeskakuma-refugee-camp-aka-think-your-way-oppression/\} accessed 8 July 2018; Scott-Smith, 'Humanitarian neophilia'.

${ }^{45}$ Mark Neocleous, 'Resisting resilience', Radical Philosophy: Journal of Socialist Feminist Philosophy, 178 (2013), pp. 2-7.

${ }^{46}$ Nora Bardelli, 'The shortcomings of employment as a durable solution', Forced Migration Review, 58 (2018), pp. 54-5.

${ }^{47}$ See Alexander Betts and Paul Collier, Refuge: Transforming a Broken Refugee System (London: Penguin UK, 2017).
} 
there, which, in terms of population, makes it the largest camp for Syrian refugees in both Jordan and the Middle East. ${ }^{48}$ Overall, however, camp residents represent a relatively small proportion of the total number of Syrian refugees registered with UNHCR in Jordan, which totals around 660,000 . The vast majority of Syrian refugees in the country live in the 'host communities' of Jordan, primarily the large urban centres of Amman, Irbid, Mafraq, and Zarqa. The Jordanian census of December 2015 recorded a much higher number of around 1.25 million Syrians living in Jordan (refugees and non-refugees), although this number is the subject of much debate and controversy. ${ }^{49}$ Despite hosting a relatively small proportion of the Syrian refugee population, Za'tari quickly attracted a disproportionate level of funding and attention, as refugee camps often do, and has become one of the key sites of the Syria refugee response. ${ }^{50}$

As soon as the camp opened, Syrians began to conduct informal economic activity. In a fashion typical of many humanitarian settings, ${ }^{51}$ Syrians quickly began to exchange and marketise the goods that were distributed to them by humanitarian agencies, including the prefabricated container units (intended as housing) that are being used as shops. According to a 2014 humanitarian assessment, the types of shops most commonly found in Za'tari are mini markets, clothes shops, shoe shops, jewellery shops, phone and Internet shops, and restaurants and bakeries. Less numerous but also present are currency exchanges and animal/pet shops. ${ }^{52}$ The number of businesses in the camp is estimated by UNHCR to be around $3,000 .^{53}$ In 2014 , it was estimated that the value of economic activity in the market exceeded $\$ 12$ million monthly, although the informality of the businesses makes such figures challenging to ascertain with accuracy. ${ }^{54}$ In contrast to Northern donors' aforementioned focus on women 'entrepreneurs', the market in Za'tari is staffed overwhelmingly by men, who in 2014 constituted 96 per cent of those working in the market. Around half of the businesses recorded at that time employed staff, a majority of whom were family members, and who typically were not paid a wage. ${ }^{55}$

Humanitarian responses to Syrians' creation of the market were complex and at times contradictory. Humanitarian actors would lament that Syrians were using resources in ways humanitarians had not envisaged, and were selling them on at much lower prices than humanitarian actors had paid for them. ${ }^{56}$ They also undertook extensive efforts to limit Syrians' capacities to reshape the life of Za'tari, as is evidenced by UNHCR's 2013 Governance Plan, which foresaw a large-scale spatial reorganisation of the camp. ${ }^{57}$ Nevertheless, according to multiple interviewees who worked in the camp, many humanitarian employees in Za'tari were from the beginning, at least relatively speaking, somewhat willing to accommodate Syrians' independent economic

\footnotetext{
${ }^{48}$ All population figures for Syrian and other refugees are taken are from the UNHCR Syria Refugee Response Inter-Agency Information Sharing Portal, available at: $\{$ http://data.unhcr.org/syrianrefugees/country.php?id=107 $\}$ accessed 14 September 2019.

${ }^{49}$ See Katharina Lenner, 'Blasts from the Past: Policy Legacies and Memories in the Making of the Jordanian Response to the Syrian Refugee Crisis', EUI Working Papers (Florence: European University Institute, 2016).

${ }^{50}$ Betts, Bloom, and Weaver, 'Refugee Innovation'; Author's interview with ex-international agency employee, Amman, Jordan, 13 November, 2015; Barbara Harrell-Bond, 'Camps: Literature review', Forced Migration Review, 2 (1998), pp. 223; Lewis Turner, 'Explaining the (non-)encampment of Syrian refugees: Security, class and the labour market in Lebanon and Jordan', Mediterranean Politics, 20:3 (2015), pp. 386-404.

${ }^{51}$ Karen Jacobsen, The Economic Life of Refugees (Bloomfield, CT: Kumarian Press, 2005).

${ }^{52} \mathrm{REACH}$, 'Market Assessment in Al Za' atari Refugee Camp in Jordan: Assessment Report' (Amman: REACH, November 2014), p. 8.

${ }^{53}$ Jordan - Zaatari Camp Fact Sheet June 2018', UNCHR, available at: \{https://data2.unhcr.org/en/documents/download/ 63931 \} accessed 6 August 2018.

${ }^{54}$ Sara Elizabeth Williams, 'Profit and Loss on the "Champs-Élysées” of a Syrian Refugee Camp', The Business of Fashion, available at: \{https://www.businessoffashion.com/articles/global-currents/profit-loss-champs-elysees-syrian-refugee-camp\} accessed 10 August 2018.

${ }^{55 ‘}$ Market Assessment in $\mathrm{Al} \mathrm{Za'atari} \mathrm{Refugee} \mathrm{Camp} \mathrm{in} \mathrm{Jordan',} \mathrm{REACH,} \mathrm{pp.} \mathrm{12-15,} 18$.

${ }^{56}$ Field notes, 3 December 2015, 30 June and 21 July 2016.

${ }^{57}$ 'Zaatari Governance Plan', UNHCR, available at: \{http://reliefweb.int/report/jordan/zaatari-governance-plan-june-2013\} accessed 3 January 2015.
} 
activities, recognising that Syrians were creating livelihoods for themselves. Moreover, as I will explore in detail, many humanitarian workers' impressions of the market are extremely positive. But the leadership of UNHCR Jordan in particular, which is close to the Jordanian government, and held accountable by the government for UNHCR's actions in the country, was deeply concerned by the ways in which the camp was developing, as was the Jordanian government. ${ }^{58}$

Given the history and presence of de facto permanent Palestinian refugee camps in the country, ${ }^{59}$ for many Jordanian governmental and non-governmental actors, Syrians' transformation of Za'tari was read as an indication that the camp would also become a non-temporary feature of Jordanian life, with associated concerns about both security and demographics. ${ }^{60}$ The entity created within the Ministry of Interior to coordinate and oversee the government's response to Syrian refugees, the Syrian Refugee Affairs Directorate (SRAD), put in place regulations that spoke directly to these concerns. For example, SRAD insisted that no concrete or breezeblocks be brought into the camp, although occasionally they were visible. The shopkeepers I met were keen to emphasise that they abided by the restrictions put in place by the government, ${ }^{61}$ which is unsurprising, given that shops are regularly shut down for (perceived) infractions of the rules governing the camp. ${ }^{62}$

The varied responses of humanitarian actors reflect, firstly, the multiple individuals and agencies that together constitute the 'refugee response', and the range of (at times divergent) agendas they hold. Secondly, these responses reflect the complexities that humanitarians experience in attempting to maintain productive working relationships with the host government, while recognising that Syrians were demonstrating the 'resilience' and 'adaptability' demanded of them, but while also wishing to govern Za'tari in authoritarian ways. Syrians were meant to be 'self-reliant', but not in ways that demonstrated what Mark Duffield terms a 'radical autonomy' from aid agencies. ${ }^{63}$ The result of this was that despite humanitarian and state actors attempting (with some considerable success) to restrict, constrain, and regulate the market, Syrians living in Za'tari have built and shaped an informal economy that is a central feature of the camp's economy and wider life. While this market generated humanitarian and governmental concerns, regulations, and repressions, as I shall now explore, it also generated surprise, applause, and at times even amazement.

\section{'The Syrians are amazing!'64 Syrian 'entrepreneurship' and humanitarian anti-blackness}

The camp market and Syrians' 'entrepreneurship' were frequent topics of conversation among humanitarian workers, who often commented on the speed of the market's development, the range of goods it provided, and the 'creativity' and 'ingenuity' that it demonstrated. Whether I had seen the market was often the first question I was asked by someone who found out I had visited Za'tari. Humanitarian conversations about the market were often extremely positive, and regularly expressed surprise, shock, and admiration that refugees living in a refugee camp could make this happen. While, as Heaven Crawley has pointed out, '[a]ll that connects [refugees to each other] is their "refugeeness" 65 the category of the refugee, and the prevailing

\footnotetext{
${ }^{58}$ Author's interview with ex-international agency employee (2015); Author's interview with ex-NGO worker, Amman, Jordan, 10 December 2015; Author's interview with ex-UNHCR employee, Amman, Jordan, 6 February 2016.

${ }^{59}$ For Palestinian camps in Jordan, see Luigi Achilli, 'Al-Wihdat refugee camp: Between inclusion and exclusion', Jadaliyya, available at: \{http://www.jadaliyya.com/pages/index/20831/al-wihdat-refugee-camp_between-inclusion-and-exclu\} accessed 19 February 2015.

${ }^{60}$ Field notes, 27 October and 3 November 2015, 21 July 2016.

${ }^{61}$ Field notes, 21 July and 1 August 2016.

${ }^{62}$ Betts and Collier, Refuge.

${ }^{63}$ Duffield, 'The liberal way of development and the development'.

${ }^{64}$ Author's interview with human rights activist, Amman, Jordan, 6 December 2015.

${ }^{65}$ Heaven Crawley, 'Why we need to protect refugees from the "big ideas" designed to save them', The Independent, available at: \{https://www.independent.co.uk/voices/refugee-immigration-europe-migrants-refugia-self-governance-a8467891. html accessed 10 August 2018.
} 
understandings of refugees in the South as feminised, depoliticised, and dependent on humanitarian organisations, would appear in this context to be shaping the expectations of many of those who encounter new populations of refugees. One interviewee told me how, when she saw the market, 'I felt ... I loved it a lot, they created a life. They have shops, markets, butcher shops, everything! Everything!' ${ }^{66}$ While in the market, another used the same word - 'everything' to describe what one could buy there, before elaborating about the 'excellent' conditions of life for Syrians in $\mathrm{Za}^{\text {'tari. }}{ }^{67}$ Another interviewee asked if I had been to Za'tari myself, and if I had seen 'what the Syrians are doing? They have turned the logic of the camp on its head ... The Syrians are amazing! ${ }^{68}$

In the aforementioned proclamations, the racialised nature of humanitarian workers' reactions is implicit; the racialisation is present in the perceived divergence of Syrians from the prevailing construction of refugeehood previously discussed, in which 'Africa' is central, and in which 'Africanness [is] conflated with (unremarkable) blackness.' ${ }^{69}$ As Wolfe argued, 'race and place are inextricable'. ${ }^{70}$ However, explicit comparisons between Syrians and 'African' refugees were also very common. While sometimes these comparisons referred to 'Africa' en masse, at other times they referred to specific country contexts. Even in these latter examples, however, the refugees in question were typically designated as either 'African' or simply 'refugees', with no mention of nationality, country of origin, or any other more specific designation. For example, one former UNHCR worker told me over dinner that they had never met a refugee who had asked for a job until they came to the Middle East and worked with Syrians. Refugees in Kenya would always want more money or material things from UNHCR, but they would never ask for a job; they didn't appear to consider work to be important. Syrians, however, this interlocutor continued, were a proud people, who did not want to beg. ${ }^{71}$ Entirely unsurprisingly, researchers have found that refugees in a range of African contexts have been imaginative, resourceful and industrious. ${ }^{72}$ Yet these attributes have often been unrecognised by humanitarian actors, and have until recently rarely been designated as 'entrepreneurship'. Instead, humanitarian actors have often perpetuated the idea that there is a widespread 'dependency mentality' among refugee populations. That is, humanitarians help to create the very 'dependency' that they bemoan. ${ }^{73}$

These explicit comparisons between Syrians and 'Africans' appeared to be one of the central ways through which many humanitarians' understandings of, and relationships with, Syrian refugees were mediated. While the substance of the comparisons was varied, Syrian refugees were invariably compared favourably to 'African' refugees, and were always positioned higher on perceived civilisational hierarchies. For example, I was told that unlike Africans, who are used to experiencing food shortages, Syrian refugees would not tolerate eating the same food that was provided by humanitarians each day. Humanitarian actors should run literacy programmes in Za'tari because they worked so well 'in Africa'. Za'tari was not a 'typical camp', in which the military is in control (a questionable empirical claim), ${ }^{74}$ but 'that's how it works in Africa'. Many humanitarian workers also considered Syrian refugees' demands and expectations to be much higher than those of 'Africans', a commentary that speaks to some of the challenges that

\footnotetext{
${ }^{66}$ Author's interview with humanitarian worker, Amman, Jordan, 28 March 2016.

${ }^{67}$ Field notes, 27 October 2015.

${ }^{68}$ Author's interview with human rights activist (2015).

${ }^{69}$ Benton, 'Risky business', p. 194.

${ }^{70}$ Wolfe, Traces of History, p. 16.

${ }^{71}$ Field notes, 18 December 2015.

${ }^{72}$ Gaim Kibreab, 'The myth of dependency among camp refugees in Somalia 1979-1989', Journal of Refugee Studies, 6:4 (1993), p. 321; see also see Easton-Calabria and Omata, 'Panacea for the refugee crisis?'.

${ }^{73}$ Barbara Harrell-Bond, Imposing Aid: Emergency Assistance to Refugees (Oxford: Oxford University Press, 1986); Kibreab, 'The myth of dependency among camp refugees in Somalia 1979-1989'.

${ }^{74}$ See Lewis Turner, 'Challenging Refugee Men: Humanitarianism and Masculinities in Za tari Refugee Camp' (PhD thesis, SOAS University of London, 2018).
} 
humanitarian agencies perceive they have faced transferring their operations to 'middle-income' countries, to work with populations from other 'middle-income' countries. ${ }^{75}$

This analysis demonstrates, as Benton has argued, that 'race operates in even the most mundane aspects of [humanitarian] service delivery'. ${ }^{76}$ Reflecting 'overlapping racial and geopolitical hierarchies' ${ }^{77}$ 'Africa' appears 'at the bottom of the development hierarchy and outside of modernity', ${ }^{78}$ and 'black people ... serve as a foil against which' others are assessed. ${ }^{79}$ In the context of Za'tari, it was very common to encounter 'Africa' and 'Africans' being homogenised and constructed as passive, dependent, backward, and impoverished, reinforcing well-established humanitarian and development discourses. ${ }^{80}$ These constructions of 'Africa' and 'Africans' also occurred outside of direct comparisons with Syrian refugees. One interviewee recalled a senior UNHCR employee, when referring to a longstanding refugee camp in Kenya and the ongoing sanitation programmes in the camp, saying that in 30 years these people might have learned to clean up their own shit by now. ${ }^{81}$ One more critical interviewee described these sentiments as reflecting and emanating from the 'sector mentality that all refugees are Africans, and all Africans are illiterate'. ${ }^{82}$

Many of the interlocutors who would draw comparisons between Syrian refugees and 'African' refugees were so-called 'international' humanitarian workers who had previously worked 'in Africa'. Many of them spoke of wanting to go 'back to Africa' after their postings working on the Syria crisis. 'Africa' appeared to be the 'default' space of humanitarianism, and where many of these individuals had learned how to be humanitarians. Most of these people were white and held European or North American citizenship. The comparisons, however, were by no means made exclusively by humanitarian workers of this profile, but also by Jordanian (so-called 'local') humanitarians. While the categories of 'international' and 'local' humanitarians both contain a range of experiences, positionalities, and perspectives, it was noticeable that, in comparison with their 'international' counterparts, Jordanian interlocutors appeared to be less frequently able to draw on personal experiences of 'Africa' and 'Africans', yet analogous comparisons would still regularly be deployed. Comparative statements often came in a formulation such as that if it was possible to do a certain sort of programme with refugees in Somalia/Kenya/ 'Africa', then it must be possible to do it in Jordan with Syrian refugees. One Jordanian interlocutor argued that there was much more control and order in Jordan, compared to 'Africa' where large swathes of territory were essentially ungoverned, and that 'international' humanitarians should adapt their expectations accordingly, and consult with the Jordanian authorities before carrying out their plans, even if they were not used to doing so 'in Africa'. ${ }^{83}$

In addition to influencing perceptions of Syrians, it is important to note that this humanitarian anti-blackness has very important implications for other nationalities of refugees who seek asylum in Jordan, such as the approximately 6,000 Sudanese and 750 Somalis registered with UNHCR. While there are multiple concurrent rationalities that shape Jordanian and

\footnotetext{
${ }^{75}$ Field notes, 15 October, 27 October, 12 December, and 18 December 2015, 18 January and 9 June 2016; for debates on UNHCR in 'middle-income' contexts, see Betts, Bloom, and Weaver, 'Refugee Innovation'; Jeff Crisp, 'Finding space for protection: an inside account of the evolution of UNHCR's urban refugee policy', Refuge: Canada's Journal on Refugees, 33:1 (2017), pp. 87-96.

${ }^{76}$ Benton, 'Risky business', p. 190.

${ }^{77}$ Ibid., p. 190.

${ }^{78}$ Daley, 'Rescuing African bodies', p. 376.

${ }^{79}$ Benton, 'African expatriates and race in the anthropology of humanitarianism', p. 268.

${ }^{80}$ See A. M. Gahutu, 'Towards grim voyeurism: the poetics of the gaze on Africa', Rwanda Journal, Series A: Arts and Humanities, 1:1 (2016), pp. 77-89; Grovogui, 'Come to Africa'; Heron, Desire for Development; Repo and Yrjölä, 'The gender politics of celebrity humanitarianism in Africa'; Wilson, Race, Racism and Development.

${ }^{81}$ Author's interview with ex-UNHCR employee (2016).

${ }^{82}$ Author's interview with ex-NGO worker (2015).

${ }^{83}$ Field notes, 15 November, 28 November and 18 December 2015, 9 April, 9 June and 25 July 2016.
} 
humanitarian policies towards refugees from these countries, ${ }^{84}$ research has demonstrated the lack of support and international attention they receive, even when, for example, 800 Sudanese refugees (mostly Darfuris) were deported to Sudan by the Jordanian government in $2015 .^{85}$ Somali and Sudanese refugees themselves have consistently highlighted their experiences of racism and discrimination in Jordan, from 'host communities', the Jordanian government, and humanitarian actors. $^{86}$

This anti-blackness should be understood within the specificities of the Jordanian context and broader globalised hierarchies of race. For example, it occurs within a space with a pertinent 'legacy of an Arab nationalism that deemed Semitic Arab-ness superior to other types', ${ }^{87}$ and within a wider region in which distinguishing 'Arabness' from 'blackness' has been an important aspect of national identity formation. ${ }^{88}$ Simultaneously and crucially, however, this anti-blackness is also a reproduction of 'the racial ordering system which has been continuous, yet morphing in form, from colonialism ... into the present' ${ }^{89}$ As was noted earlier, literatures within IR, Black studies, and other disciplines have all made clear that these hierarchies of race cannot be understood separately from colonialism, slavery, and capitalism. ${ }^{90}$ As scholars have furthermore demonstrated, these hierarchies have long been interwoven throughout humanitarianism, as well as parallel fields such as development. ${ }^{91}$

Syrians are not only being rendered distant from '(unremarkable) blackness', however. ${ }^{92}$ In a further continuity with colonial designations and hierarchies, Syrians' 'entrepreneurship' is also seen, by some humanitarians and academics, as an embodiment of their status as 'Levantines'. Deriving from the French word for 'rising', in its broader sense 'the Levant' can refer to the areas of land on the shores of the Eastern Mediterranean, but is also used to refer to the historic region of Syria, which incorporated present-day Syria, Lebanon, Jordan, and Palestine/Israel. Although the designation of 'Levantine' has varied and shifting connotations, often related to mobility, diversity, and rootless cosmopolitanism, ${ }^{93}$ 'entrepreneurship' is central to many understandings of 'Levantinism' and to readings of the peoples of the region, and especially of the diasporas of Syria and Lebanon specifically. In numerous, diverse contexts, Syrians and Lebanese have been 'known' for embodying 'entrepreneurial' traits. In Brazil, they were able to claim and obtain an 'ambivalent respectability' within the nation through their 'alleged innate commercial essence'. ${ }^{94}$ The Lebanese have been similarly referred to as one of the world's leading 'trading diasporas', emerging in West Africa as 'a significant entrepreneurial class'. ${ }^{95}$

The manifestations of these ideas within and about Za'tari were again numerous. Curtis Ryan, in a 2014 article on the camp, noted that Syrians' 'resilience' and attempts to build community in

\footnotetext{
${ }^{84}$ Rochelle Davis, Grace Benton, Will Todman, and Emma Murphy, 'Hosting guests, creating citizens: Models of refugee administration in Jordan and Egypt', Refugee Survey Quarterly, 36:2 (2017), pp. 1-32.

${ }^{85}$ 'Jordan: Deporting Sudanese Asylum Seekers', Human Rights Watch, available at: $\{$ https://www.hrw.org/news/2015/12/ 16/jordan-deporting-sudanese-asylum-seekers\} accessed 13 September 2019.

${ }^{86}$ See Rochelle Davis, Abbie Taylor, Will Todman, and Emma Murphy, 'Sudanese and Somali refugees in Jordan', Middle East Report, 279 (2016), pp. 2-10.

${ }^{87}$ Ibid., p. 3.

${ }^{88}$ Eve Troutt Powell, A Different Shade of Colonialism: Egypt, Great Britain, and the Mastery of the Sudan (Berkeley, CA: University of California Press, 2003).

${ }^{89}$ Lisa Tilley and Robbie Shilliam, 'Raced markets: an introduction', New Political Economy, $23: 5$ (2018), pp. 534-43.

${ }^{90}$ See fns 17 and 20.

${ }^{91}$ See Benton, 'African expatriates and race in the anthropology of humanitarianism'; Benton, 'Risky business'; Arturo Escobar, Encountering Development: The Making and Unmaking of the Third World (Princeton: Princeton University Press, 1994); Wilson, Race, Racism and Development.

${ }^{92}$ Benton, 'Risky business', p. 194.

${ }^{93}$ See Amr Kamal, 'Ghostly labor: Ethnic classism in the Levantine prism of Jacqueline Kahanoffs Jacob's Ladder', International Journal of Middle East Studies, 49:2 (2017), pp. 255-75.

${ }^{94}$ Karam, 'A cultural politics of entrepreneurship in nation-making', p. 320.

${ }^{95}$ Emmanuel K. Akyeampong, 'Race, identity and citizenship in black Africa: the case of the Lebanese in Ghana', Africa: Journal of the International African Institute, 76:3 (2006), p. 308.
} 
the camp are 'casually ascribed', by '[m]any observers - and some refugees themselves ... to a natural entrepreneurial trait of the Syrian nation. ${ }^{96}$ In a televised interview, Kilian Kleinschmidt, the then UNHCR Senior Field Coordinator (the most senior UNHCR role in Za'tari - also known as the 'camp manager') declared that it was 'very natural [Syrians] have set up shops, because they are traders' ${ }^{97}$ A report by the University of Oxford's Refugee Studies Centre claims that ' $\mathrm{i}$ ]n the Levant region, Syrians are well known for their entrepreneurial endeavours. Many of the refugees arriving to Za' atari are highly skilled ... Many were traders in Syria. ${ }^{98}$

At the same time, however, it is important to note how localised such racialised understandings of 'entrepreneurship' and work can be. In Jordan's Special Economic Zones, for example, many factories have built labour regimes centred on the social isolation and exploitation of migrant workers, predominantly women, from South Asia. When offered the chance to hire Syrian refugees, many employers were uninterested, assuming, in contrasting racialised hierarchies, that Syrians would be unproductive, 'like Jordanians', whom factories are legally obliged to employ a quota of when using migrant workers. ${ }^{99}$ As John Chalcraft has explored in the context of Syrian migrant workers in Lebanon, "Syrians are "known" to be docile, hard-working, uncomplaining and ready to follow orders ... Syrians are said to be uneducated and "backward" or "rural". 100 Syrians are thus 'known' very differently in different contexts, even when those contexts are in very close geographical proximity. Humanitarian portrayals of Syrians online attempt to render them 'known' as 'entrepreneurs'. These communications target a wider, but at the same time particular, audience.

\section{'You wouldn't mind if they moved into your neighbourhood': ${ }^{101}$ Marketing Za'tari's 'entrepreneurs'}

In humanitarian actors' public communications, explicit racial comparisons are absent, but the implicit positioning of Syrians and their 'entrepreneurship' relative to racial hierarchies continues. This can be seen in UNHCR's online promotion of Syrians' 'entrepreneurship', which is a recurring theme in humanitarian portrayals of Za'tari camp. '\#Innovation starts with affected communities. Great examples from @ZaatariCamp', reads a September 2015 tweet from @UNHCRInnovation, a Twitter account run by the UNHCR Innovation Service. ${ }^{102}$ The '@ZaatariCamp' it mentions is Za'tari's Twitter handle, which made it, in October 2013, the first refugee camp in the world to have its own Twitter account. ${ }^{103}$ Run by UNHCR staff in the camp, rather than Syrian refugees themselves, its profile describes the camp as 'vast, dusty and unpredictable' and a 'remarkable stretch of desert [that] is home to 80,000 Syrian refugees'. ${ }^{104}$ The market, where much of this 'innovation' and 'entrepreneurship' happens, has,

\footnotetext{
${ }^{96}$ Curtis Ryan, 'Refugee Need and Resilience in Zaatari', Middle East Research and Information Project, available at: \{http:// www.merip.org/refugee-need-resilience-zaatari\} accessed 4 August 2014.

${ }^{97}$ UNHCR, 'A Day in the Life: Za'atari - Episode 1: Welcome to Za'atari', YouTube, available at: \{https://www.youtube. com/watch? $\mathrm{v}=\mathrm{o} 4$ OIVW0waEo\&list=PLtPw-Y91GlmWQ442W6zA-oeeXxYI1W3HF $\}$ accessed 17 January 2017.

${ }^{98}$ Betts, Bloom, and Weaver, 'Refugee Innovation', p. 19.

${ }^{99}$ Katharina Lenner and Lewis Turner, 'Making refugees work? The politics of integrating Syrian refugees into the labor market in Jordan', Middle East Critique, 28:1 (2019), pp. 65-95.

${ }^{100}$ John Chalcraft, 'Labour in the Levant', New Left Review, 45 (2007), p. 39.

${ }^{101}$ Author's interview with Jared Kohler, photographer formerly contracted to UNHCR Jordan, Amman, Jordan, 28 March 2016.

${ }^{102}$ UNHCR Innovation, ‘\#Innovation Starts with Affected Communities. Great Examples from @ZaatariCamp', Twitter post, available at: \{https://twitter.com/UNHCRInnovation/status/641627674562183168\} accessed 13 February 2017.

${ }^{103}$ Dina Rickman, 'The story behind the first refugee camp on Twitter', indy100, available at: $\{$ http://indy100.independent. co.uk/article/the-story-behind-the-first-refugee-camp-on-twitter--xJzolhh3vl\} accessed 28 February 2017.

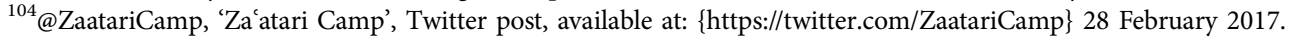


according to @ZaatariCamp, 'helped refugees in finding normalcy in displacement'. ${ }^{105}$ One of these 'entrepreneurs' is a man pictured in his perfume shop in October 2013. The tweet contains a quotation that reads 'I needed to live and I need to work ... I also needed to change the smell of this place', followed by the words 'Respect. \#entrepreneur.'106

As Stuart Hall has argued, the intertextuality of images means that they are read and understood in the context of other images that may not simultaneously be present. ${ }^{107}$ This insight can be mobilised to understand how the passive, depoliticised, feminised, and racialised figure of the refugee remains the implicit basis for comparison in profiles of Syrians' 'entrepreneurship'. In 2015, for example, UNHCR's website offered a profile of a new pizza delivery service that opened in the camp, and of Abu Mahmood, the 'Syrian entrepreneur [who] has brought a slice of normal life to refugees'. ${ }^{108}$ The article quotes Nasser Touaibia, then a UNHCR communications officer, who argues that the new shop is a demonstration of the fact that Syrian refugees in Za'tari 'are not just ... waiting for humanitarian agencies to create opportunities for them ... [they] are proactive, they are very creative, and they come up with new ideas'. ${ }^{109}$ UNHCR Innovation also draws attention to Abu Mahmood, whose story is the first in an article that profiles ' 10 refugees who will change your perception of entrepreneurship. ${ }^{.10}$ Two of the other nine are also Syrian refugees living in Za'tari. Bizarrely, the website of UNHCR Innovation has a 'Jordan' page that only contains a picture of Abu Mahmood and his pizzas, without even so much as a caption. ${ }^{111}$ In yet another article on the same pizza shop, Touaibia describes Syrians in Za'tari as 'not the type of people that would sit around, cross their hands and wait for you to do something for them. They are actually very creative and very active.' ${ }^{\text {,12 }}$ Which 'types of people' do 'sit around' waiting for humanitarians to provide for them, one might wonder? Is it imagined that other ('African'?) refugees sit waiting, outside of time, while Syrians demonstrate the 'hustling' that is central to work (and life) under neoliberalism ${ }^{113}$

The depictions of 'refugee entrepreneurship' among Syrians in Za'tari rarely include explicit discussions of gender, either. As noted above, the overwhelming majority of Syrians who have started businesses and/or work in Za'tari's market are men, reflecting, among other factors, their easier access to capital, the domestic and caring work done by women in the camp, and gendered expectations about work and responsibilities. ${ }^{114}$ While there are humanitarian and other profiles of both refugee men and women 'entrepreneurs' in the camp, ${ }^{115}$ it is striking that the gendered motivations of many men for wanting to become 'entrepreneurs' - to fulfil

\footnotetext{
${ }^{105} @$ ZaatariCamp, 'One of the 2000+ Shops Run by @Refugees in \#Zaatari. This Market Helped Refugees in Finding Normalcy in Displacement', Twitter post, available at: $\{$ https://twitter.com/ZaatariCamp/status/687273642200305664\} accessed 9 March 2017.

${ }^{106} @ Z$ ZatariCamp, “I Needed to Live and I Need to Work ... I Also Needed to Change the Smell of This Place.” Respect. \#entrepreneur', Twitter post, available at: \{https://twitter.com/ZaatariCamp/status/395468308469661696\} accessed 24 September 2017.

${ }^{107}$ Stuart Hall, 'The spectacle of the "other", in Stuart Hall (ed.), Representation: Cultural Representations and Signifying Practices (London and Thousand Oaks, CA: Sage, 1997), p. 232.

${ }^{108}$ Charlie Dunmore, 'Syrian Refugee Starts Pizza Delivery Service in Za'atari Camp', UNHCR, available at: \{http://www. unhcr.org/54f43af26.html\} accessed 18 June 2016.

${ }^{109}$ Ibid.

${ }^{110}$ Lauren Parater, '10 Refugees Who Will Change Your Perception of Entrepreneurship', UNHCR Innovation, available at: \{http://www.unhcr.org/innovation/10-refugees-who-will-change-your-perception-of-entrepreneurship/\} accessed 2 August 2018.

111،Jordan', UNHCR Innovation, available at: $\{$ http://www.unhcr.org/innovation/jordan/ $\}$ accessed 8 October 2018. I am grateful to Mirjam Twigt for drawing my attention to this webpage.

${ }^{112}$ Megan Specia, 'Syrian refugee camp gets pizza delivery service', Mashable, available at: \{http://mashable.com/2015/02/ 17/syrian-refugee-pizzeria/\} accessed 20 February 2015.

${ }^{113}$ Lester K. Spence, Knocking the Hustle: Against the Neoliberal Turn in Black Politics (Brooklyn, NY: Punctum Books, 2015).

${ }^{114}$ Turner, 'Challenging Refugee Men'.

${ }^{115}$ See Betts, Bloom, and Weaver, 'Refugee Innovation'; Parater, '10 Refugees'.
} 
gendered expectations that they be a breadwinner for their families ${ }^{116}$ - are typically not discussed. In the context of the widespread demonisation of refugees, particularly those from predominantly Arab and Muslim contexts such as Syria, ${ }^{117}$ male 'refugee entrepreneurs' appear to be an acceptable face of Syrian refugee men for UNHCR to promote to a wider audience, even if the masculinities driving much of their 'entrepreneurship' remain absent from the narratives.

The focus on Syrian 'refugee entrepreneurs' is part of a deliberate strategy used by UNHCR to counter prevailing negative images of Syrian refugees and thereby to attempt to help facilitate donations and resettlement opportunities. As scholars have long noted, UNHCR is highly dependent on voluntary donations from States, which can influence its portrayal of refugees, and which issues it highlights or remains silent about. ${ }^{118}$ According to Jared Kohler, a photographer formerly contracted to UNHCR Jordan, UN agencies in the camp believed that, from an advocacy standpoint, they should not highlight stories of abuse and violence in Za'tari, but rather look 'for a feel good story'. Kohler explained that in his experience, humanitarians seeking to advocate for refugees appeared to typically believe that in contexts of sub-Saharan Africa, the dire material circumstances, and therefore needs, of refugees can be clearly captured and communicated to middle-class, Western audiences. Syrians, however, he continued, are from a 'middle-income', non-African country, and are subject to widespread Islamophobia and anti-Arab prejudice. In this context, it appeared that humanitarian workers believed that more sympathy and acceptance could be created among these same middle-class, Western audiences, who are imagined as white, if Syrians were portrayed as 'innovators' and 'entrepreneurs', as people who 'you wouldn't mind if they moved into your neighbourhood'. As was discussed above, the abstract ideal of 'entrepreneurship' is, for many people, associated with whiteness (as well as masculinity, mobility, class privilege, abstract thinking, and bodily ability). Syrians are therefore able to be perceived as being closer to whiteness (and these other subject positions), through the construction of them as 'entrepreneurs', in contrast to humanitarian imagery and portrayals attempting, as in the case of refugees in sub-Saharan Africa, to generate pity. Put plainly, the idea is, in Kohler's words, 'to make them look white, so to speak'. 119

The marketing of the Syrians of Za'tari as 'entrepreneurs' also took place within the camp itself, where tours for visiting delegations were a daily occurrence. ${ }^{120}$ One former camp worker I interviewed recalled observing Google employees being shown around the camp by UNHCR. He recounted how the visitors would marvel at 'how innovative and entrepreneurial this guy is. He started his own bakery from nothing.' This kind of focus and formulation can have the effect of deflecting attention away from other questions, such as why he was living in a refugee camp with 'nothing' from which to build a living, and the political efforts and solidarity that would be needed to change that situation. The man in question, I was told, had been a baker in Syria for decades. ${ }^{121}$ While such sentiments are presumably intended as a 'compliment', I would nonetheless argue, following the aforementioned interviewee, that these reactions to the market represent Syrians' survival strategies being 'manipulated ... into "innovation" because it has been discovered by Westerners'. ${ }^{122}$

Syrians I spoke with often appeared to feel a real sense of achievement about the fact that they had built a vibrant market under such politically authoritarian and economically difficult conditions, and to be pleased by the reputation they had gained for being hard-working and creative. ${ }^{123}$ It is not possible, in a single article, to also explore in-depth refugees' reactions to humanitarian

\footnotetext{
${ }^{116}$ Turner, 'Challenging Refugee Men'.

${ }^{117}$ Pruitt, Berents, and Munro, 'Gender and age in the construction of male youth'.

${ }^{118}$ See Johnson, 'Click to donate'; Loescher, The UNHCR and World Politics.

${ }^{119}$ Author's interview with Jared Kohler (2016).

${ }^{120}$ Field notes, 21 July 2016.

${ }^{121}$ Author's interview's with ex-NGO worker (2015).

${ }^{122}$ Ibid.

${ }^{123}$ Field notes, 21 July and 1 August 2016.
} 
narratives about them, which will of course always be varied. Elsewhere I have examined at length Syrians' relationships to work and the market in Za'tari, and the contestations that they were engaged in with humanitarians on these questions. ${ }^{124}$ I would note, however, that in my experience comparisons with 'Africans' were simply absent from Syrians' discussions of the market they had built, the services they were provided, and their relationships with humanitarians, nor did they raise with me the fact that humanitarians made these comparisons. These narratives came from humanitarian workers, and I was exposed to them, in ways it appears many Syrians were perhaps not, because of my positionality and privilege. From the expectant looks of agreement, and the casual ways in which the comparisons were deployed, I came to believe that many humanitarians expected me - a white, male British researcher of humanitarianism who regularly visited the camp with NGOs - to understand and identify with their visions of refugees and of 'Africa'. This of course does not mean that all humanitarians stated or agreed with such comparisons, but it was nonetheless notable that, in my experience, they were not challenged when expressed in humanitarian group settings.

The narratives of Syrian 'entrepreneurship', and the fascination with the ability of refugees to undertake such 'entrepreneurship', are not only found in humanitarian production. One can also find them regularly (re)produced in the international English-language news media. $A B C$ News reports that 'Syrian entrepreneurs thrive' in the camp, which has 'mushroomed as Syrians set up shop', according to The Guardian. ${ }^{125}$ The street that houses the most shops is often referred to, by humanitarian workers, in the press, and in academic production, as the 'Champs-Élysées', after the famous, high-end shopping boulevard in Paris. ${ }^{126} B B C$ News claims that Za'tari, with this 'Champs-Élysées', is a 'fertile ground for small businesses'. ${ }^{127}$ Sometimes this designation becomes the 'Shams-Élysées', merging the names of the French street and the historical name for greater Syria (al-Sham), which can also refer to Damascus and its environs. ${ }^{128}$ This name was coined not by Syrians, however, but by French aid workers, who were stationed in a clinic near the market as it was developing. ${ }^{129}$ Syrians simply refer to the streets as 'the market' (al-suq). Even the ways in which areas of the market are named thus appear to reflect the perspectives of non-Syrians, and become part of how the camp is imagined, reported, and discussed by outsiders.

Troublingly for academic knowledge production on refugees and humanitarianism, these same ideas on 'entrepreneurship' can be found in scholarship about Za'tari. In Lionel Beehner's article in Journal of International Affairs, he describes the 'do-it-yourself Syrians in Za'tari as 'a unique breed of refugees', because they were, he claims, unaccustomed to state officials offering free public goods, and because 'there is no equivalent of a civil society in Syria that would replicate what

\footnotetext{
${ }^{124}$ Turner, 'Challenging Refugee Men'.

${ }^{125}$ See Amy Guttman, 'Syrian entrepreneurs thrive in refugee camp', ABC News, available at: \{http://www.abc.net.au/news/ 2016-11-22/syrian-entrepreneurs-thrive-in-zaatari-refugee-camp/8009324\} accessed 3 February 2017; Mark Tran, 'Jordan's Zaatari refugee camp mushrooms as Syrians set up shop', The Guardian, available at: \{https://www.theguardian.com/global-development/2013/nov/18/jordan-zaatari-refugee-camp-syria-shops $\}$ accessed 3 February 2017.

${ }^{126}$ See, for example, Lionel Beehner, 'Are Syria's do-it-yourself refugees outliers or examples of a new norm?', Journal of International Affairs, 68:2 (2015), pp. 157-75; Dale Gavlak, 'Zaatari Syrian refugee camp fertile ground for small businesses', $B B C$ News, available at: \{http://www.bbc.com/news/world-middle-east-28541909\} accessed 18 June 2016; Robert King, 'Strolling the Champs-Élysées with 120,000 Syrian refugees', Vice, available at: \{https://www.vice.com/en_us/article/strolling-the-champs-elysees-with-120000-syrian-refugees-0000116-v20n10\} accessed 2 February 2017; Denis Sullivan and Sarah Tobin, 'Security and Resilience Among Syrian Refugees in Jordan', Middle East Research and Information Project, available at: $\{$ http://merip.org/mero/mero101414\} accessed 7 November 2014.

${ }^{127}$ Gavlak, 'Zaatari Syrian refugee camp fertile ground for small businesses'.

${ }^{128}$ Betts, Bloom, and Weaver, 'Refugee Innovation'; Melissa N. Gatter, 'Rethinking the lessons from Za'atari refugee camp', Forced Migration Review, 57 (2018), pp. 22-4.

${ }^{129}$ Toufic Beyhhum and Nadim Dimechkie, 'The Champs-Élysées in Zaatari camp', Middle East Revised, available at: \{https://middleeastrevised.com/2015/10/09/the-champs-elysees-in-zaatari-camp/\} accessed 2 February 2017.
} 
UN officials do within Za'atari'. ${ }^{130}$ Paradoxically, considering their purported uniqueness, Syrians are also a demonstration that 'today's refugees are on average economically better off, more sophisticated, and generally more entrepreneurial than their predecessors'. ${ }^{131}$ In a similar vein to the aforementioned humanitarian production, Beehner highlights Za'tari's pizza delivery shop, that refugees in Za'tari come 'from all walks of life, income levels, and professions', and that 'the camp is seen as more "high end" than those in Africa and elsewhere'. ${ }^{132}$ Although Beehner notes the 'norms of entrepreneurship' found among refugees in Somaliland, ${ }^{133}$ nevertheless, following the logic of his argument, presumably 'Africa and elsewhere' are where Za'tari's economically worse off, less 'sophisticated' and less 'entrepreneurial' predecessors are to be found. In the wider academic production on the camp, like the humanitarian literature, the idea that Syrians in Za'tari are 'entrepreneurial' (as well as 'innovative' and 'resilient') appears to be widespread. ${ }^{134}$ A blog post by Helen Storey on the website of the Centre for Sustainable Fashion, part of the University of the Arts London, is titled, 'Za'atari Refugee Camp: How to be an Entrepreneur in Hell.' The second part of the title, we are later told, is a quotation from the UNHCR camp manager, at that time Hovig Etyemezian. ${ }^{135}$

While Syrians in Za'tari are perceived to be something of a case study for 'refugee entrepreneurship', as noted above, Za'tari is not the only context in which refugees have been depicted, in both humanitarian and academic production, as 'refugee entrepreneurs'. The aforementioned UNHCR article on refugees who will 'change your perception of entrepreneurship' includes stories of Somali refugees living in Kenya, Sudanese refugees living in Chad, and refugees from the Democratic Republic of Congo living in Uganda. ${ }^{136}$ In academic production, scholars have discussed the presence and potential of 'refugee entrepreneurs' in a range of contexts, although Kenya and Uganda appear to attract significant attention. ${ }^{137}$

The ways and extent to which racialisations are part of the (explicit and implicit) designations of 'entrepreneurship' 'on the ground' within these contexts, as well as in production about them, is a subject that merits investigation, in order to further our understandings of how humanitarian individuals and institutions 'filter the global idea of race'. ${ }^{138}$ In those investigations, it will be important to remember that different positionings of refugees - as anti-communist heroes, as depoliticised masses of women and children, and as 'entrepreneurs' - are all inextricably connected with ideas about race, as well as gender, class, and other structures. Since the generic figure of the 'entrepreneur' signifies whiteness, masculinity, mobility, class privilege, abstract thinking,

\footnotetext{
${ }^{130}$ Beehner, 'Are Syria's do-it-yourself refugees outliers or examples of a new norm', pp. 157, 168; for scholarship on the public sector and civil society in Syria, see, for example, Paul Aarts and Francesco Cavatorta (eds), Civil Society in Syria and Iran: Activism in Authoritarian Contexts (Boulder, CO: Lynne Rienner Publishers, 2012); Laura Ruiz de Elvira and Tina Zintl, 'The end of the Ba'thist social contract in Bashar Al-Asad's Syria: Reading sociopolitical transformations through charities and broader benevolent activism', International Journal of Middle East Studies, 46:2 (2014), pp. 329-49; Bassam Haddad, 'The political economy of Syria: Realities and challenges', Middle East Policy, 18:2 (2011), pp. 46-61.

${ }^{131}$ Beehner, 'Are Syria's do-it-yourself refugees outliers or examples of a new norm', pp. 160-1.

${ }^{132}$ Ibid., pp. 160, 161, 171.

${ }^{133}$ Ibid., p. 171.

${ }^{134}$ See, for example, Betts, Bloom, and Weaver, 'Refugee Innovation'; Marlen de la Chaux, 'Rethinking refugee camps: Turning boredom into innovation', The Conversation, available at: $\{\mathrm{http} / /$ theconversation.com/rethinking-refugee-campsturning-boredom-into-innovation-47718\} accessed 17 August 2018; Gatter, 'Rethinking the lessons from Za'atari refugee camp'; Sarah Deardorff Miller, 'Assessing the Impacts of Hosting Refugees', World Refugee Council Research Papers (Centre for International Governance Innovation, 2018).

${ }^{135}$ Helen Storey, 'Za' atari Refugee Camp: How to Be an Entrepreneur in Hell', Centre for Sustainable Fashion, available at: \{http://sustainable-fashion.com/blog/zaatari-refugee-camp-how-to-be-an-entrepreneur-in-hell/\} accessed 13 August 2018.

${ }^{136}$ See Parater, '10 Refugees'.

${ }^{137}$ See, for example, Betts, Bloom, and Weaver, 'Refugee Innovation'; Evan Easton-Calabria, “'Refugees Asked to Fish for Themselves”: The Role of Livelihoods Trainings for Kampala's Urban Refugees', New Issues in Refugee Research (Geneva: UNHCR, 2016); Holly A. Ritchie, 'Gender and enterprise in fragile refugee settings: Female empowerment amidst male emasculation - a challenge to local integration?', Disasters, 42:1 (2018), pp. 40-60.

${ }^{138}$ Thompson, 'Through, against and beyond the racial state', p. 50 .
} 
and bodily ability, the idea of the 'refugee entrepreneur' foregrounds and praises those refugees who are able to (be perceived to) embody these traits. Systemic structures and barriers, histories of oppression, and wider socioeconomic contexts can be sidelined, even erased, as the focus is placed upon individuals and their perceived 'entrepreneurial' qualities. ${ }^{139}$

The marketing of Syrians as 'refugee entrepreneurs' can furthermore be seen and understood within the context of a broader instrumentalisation of refugees' experiences and hardships, ${ }^{140}$ which are being used in order to attempt to portray them as 'palatable' and 'productive' potential members of societies and especially workforces. For example, according to Alexander Betts, due to their experiences refugees should be seen as 'natural entrepreneurs'. Refugees, he argues 'have to adapt - to new social networks, new markets, and new regulation. As the old adage suggests, "necessity is the mother of invention". 141 Taking this logic even further is a German non-profit recruitment agency called 'Social-Bee', which attempts to help refugees in Germany find employment. To do so, both online and on public billboards, it promotes refugees as potential workers by describing the 'soft skills' they got 'the hard way'. A Social-Bee website includes small profiles of four refugees (all men), with quotations attributed to refugees themselves, accompanied by headlines that appear to be the organisation's take on how such skills are transferable to the labour market. Set to tense and dramatic background music, Qutayba from Syria, for example, states that 'while fleeing I was arrested and interrogated for several days'. Above this quotation, in much larger letters but without quotation marks, are the words 'I am stress resistant.' Zeray from Eritrea says that he 'survived with 85 people in a small dinghy', which is presented beneath the large caption 'I'm a team player.' ${ }^{, 22}$ In their entry into the labour market, refugees' experiences are being instrumentalised, and refugees themselves are being marketed.

\section{Conclusion}

This article has argued that race is central to the ways in which refugees in $\mathrm{Za}$ 'tari are understood and depicted as 'entrepreneurs'. Within the camp, humanitarian workers deem Syrians' economic activities to distinguish them from 'African' refugees, to embody their 'Levantinism', and to present an opportunity to market Syrians to the outside world as 'entrepreneurs'. That is, to market them as embodying a subject position associated with whiteness, as well as masculinity, class privilege, and bodily ability, in order to promote Syrian refugees to intended Western audiences and donors. The 'refugee entrepreneur' thus becomes a recent instantiation of the ever-changing constructions of how refugeehood is imagined. In elaborating these arguments, the article has furthered our understandings of the underexplored relationship between humanitarianism and race. As Meera Sabaratnam argues, exposing the 'racialised hierarchies of entitlement' running through contemporary systems of aid presents a 'timely opportunity for demanding change.. ${ }^{143}$

Situating the 'refugee entrepreneurs' of Za'tari within a wider analysis of contemporary humanitarianism, this article has furthermore demonstrated that the perceptions and promotion of 'entrepreneurs' can be understood as part of a neoliberalised 'resiliency humanitarianism', which demands that its 'beneficiaries' constantly 'adapt' and 'bounce back' in contexts of disaster and displacement. At the same time, the vision of 'refugee entrepreneurship' articulates with troubling proposed reforms to the wider refugee regime, which downplay refugees' rights and

\footnotetext{
${ }^{139}$ Bardelli, 'The shortcomings of employment as a durable solution'; Knight, "New markets must be conquered”; Wilson, Race, Racism and Development.

${ }^{140}$ See, for example, Brankamp, 'TEDx Comes to the Refugee Camp'.

${ }^{141}$ Betts, quoted in Suzanne Bearne, 'Refugees turned entrepreneurs: "I needed to think about the future", The Guardian, available at: \{http://www.theguardian.com/small-business-network/2017/feb/28/refugees-turned-entrepreneurs-future-business-perserverance $\}$ accessed 8 August 2018.

${ }^{142}$ 'Soft Skills Can Come the Hard Way', Social-Bee, available at: $\{$ http://www.employ-refugees.de/\} accessed 8 August 2018, translation by Benjamin Schütze. I am grateful to Katharina Lenner for drawing my attention to Social-Bee.

${ }^{143}$ Sabaratnam, Decolonising Intervention, p. 8.
} 
foreground refugees' integration into economic markets, all undergirded by the contention that 'global capitalism can come to the rescue of the refugee system'. ${ }^{144}$ In these depictions of refugees' lives, where is the assistance that many refugees need? Where are the refugees who cannot live up to the 'entrepreneurial ideal'? Where are the structural barriers and histories of dispossession that shape their lives? And where are the refugees who actively challenge these economic hierarchies and problematic models of personhood?

People who are experiencing displacement respond to changing and challenging circumstances in ways that are diverse, and which reflect their varied pasts, presents, and (hoped-for) futures. Many of these responses are surprising to outsiders. This article has demonstrated that this surprise, and the ways in which it is mobilised, can be intricately connected to ideas about race. Designating activities as 'entrepreneurship', even if done with the intention of breaking-down dehumanising portrayals of refugees, happens within pre-existing fields of power relations. Within hierarchies of race, gender, class, ability, among others, and alongside calls for structural reform of the refugee regime towards more 'market-oriented' solutions, in which refugees will increasingly have to fend for themselves. Humanitarians, journalists, and academics promoting 'refugee entrepreneurs' as a new way in which refugeehood should be imagined must be cognisant of these complex contexts, and the colonial legacies imbricated in them. For whatever refugees' survival strategies might be, and however they might be labelled and interpreted, they are not an invitation to strip away the dwindling support structures that do still exist for refugees.

Acknowledgements. I would like to thank Laleh Khalili, Kerem Nişancioğlu, Sara Salem, and two anonymous reviewers for their very helpful and detailed comments on this work. I received valuable feedback and encouragement from fellow panellists, audiences, and discussants when presenting the paper at the 2018 meetings of the British International Studies Association in Bath and the British Society for Middle Eastern Studies in London, and at the ALMA Research Series in Freiburg. Finally, I would like to thank Adia Benton, who, at the 2017 meeting of the International Studies Association in Baltimore, encouraged me to pursue the ideas that developed into this article.

Lewis Turner is a Senior Researcher at the Arnold Bergstraesser Institute at the University of Freiburg in Germany. His research focuses on the humanitarian response for Syrian refugees in the Middle East, primarily in Jordan. It explores questions of gender (especially men and masculinities), race, labour markets, and encampment. His work has appeared in numerous journals, including International Feminist Journal of Politics; Mediterranean Politics; and Middle East Critique. $\mathrm{He}$ is the winner of the 2019 Shirin M. Rai Dissertation Prize for International Relations, awarded by the Political Studies Association, and the 2019 Michael Nicholson Thesis Prize, awarded by the British International Studies Association.

\footnotetext{
${ }^{144}$ Heaven Crawley, 'Migration: Refugee economics', Nature, 544 (2017), p. 27.
}

Cite this article: Turner, L. 2020. '\#Refugees can be entrepreneurs too!' Humanitarianism, race, and the marketing of Syrian refugees. Review of International Studies 46, 137-155. https://doi.org/10.1017/S0260210519000342 